\title{
THE SMALL AND MEDIUM ENTERPRISES AND POVERTY IN PAKISTAN: AN EMPIRICAL ANALYSIS
}

\author{
SHARAFAT ALI
}

\author{
Government Postgraduate College Kot Sultan, Layyah, Pakistan
}

\begin{abstract}
Small and Medium Enterprises (SMEs) have got very much importance in the economic growth, employment generation and poverty alleviation in the economy. The annual time series data is used for examination of impact of SMEs on poverty in Pakistan for the period of 1972 - 2008. The study utilizes Johansen cointegration and error correction mechanism to examine long run and short impacts small scale industries and other explanatory variable on poverty in Pakistan. The results of the study confirm a strong and poverty alleviating impact of small scale industries' output in Pakistan. The study the economic policy makers to focus on the establishment of formal financial markets to overcome the financial constraints faced by the SME sector in Pakistan. Simplification of lending procedures, enforcement of credit rights, and reduction in credit costs would be helpful for the establishment of robust SME sector in Pakistan.
\end{abstract}

\section{JEL CLASSIFICATION \& KEYWORDS}

- C32 - 130 - 014 - POVERTY - SMALL AND MEDIUM ENTERPRISES ॥ INCOME INEQUALITY ॥ POPULATION GROWTH

\section{INTRODUCTION}

The Small and Medium Enterprises (SMEs) have been a major concern in the economic literature. The different authors define small and medium enterprises differently. Some of the authors define SMEs in terms of capital assets while others define these enterprises in terms of skill of labor and turnover level of these firms. The Bolton Committee (1971) formulated "economic" and "statistical" definition of SMEs. According to the economic definition of SMEs a firm is independent, it is considered to be small which has relatively small share of its market place, and managed by owners themselves, or part owners in personally, and not by the medium of formalized management structure. According to statistical definition criteria small firms are characterized by the size, its contribution to GDP, the employment opportunities provided by these firms and exports, etc. and the changes in the small firm sector's economic contribution. Jordan et al (1998) define the SMEs that have fewer than 100 employees and a turnover of less than 15 million euros. The report of the United Nations Industrial Development Organizaiton-UNIDO (2002) defines SMEs in terms of number of employees and classifies these SMEs in developing and developed economies differently (see Abor and Quarty (2010). The classification of SMEs in developing country is as follows:

- micro-firms with less than five workers,

- small-firms with 5 to 19 workers,

- medium-firms with 20 to 99 employees,

- large-firms with 100 or more employees.

The Classification of SMEs in industrialized nations is given as follows:

- small firms with 99 or less employees,

- medium-firms with 100 to 500 employees,
- large firms with 500 or more workers.

The SMEs are defined by different economists differently but SMEs have recognized as an important potential sector for generation of employment opportunities and provision of livelihood forth e poor. Importance of small scale enterprises (SMEs) has been recognized all over the globe. The SMEs increase productivity growth in the economy. Increased productivity growth plays important role for the welfare of the people and reduction in poverty. SMEs not only play significant complementary role in industrialization of the economy but also act as driver of structural change. The productivity growth in the economy implies innovation in the economy. SMEs growth also enhances the degree of specialization.

An efficient network of SMEs in Pakistan is prerequisite for the establishment of robust industrialization. Government of Pakistan has declared SMEs as one of the four important drivers of growth for the Pakistan economy. SMEs play very important role in value addition and employment generation in Pakistan. SME sector is highly labor-intensive and this sector provides employment to the major part of non-agriculture labor force in Pakistan, Economic Survey (2004 - 05) issued by Ministry of Finance, Government of Pakistan. In Pakistan, SMEs constitute 90 percent of the business constitutes. This sector provides 80 percent of the employment opportunities to non-agriculture labor force, 25 percent of the total exports, 35 percent of the manufacturing value added and contributes more than 30 percent to the GDP of the economy, Economic Survey $(2009$ - 10). One-fourth of the export earnings are generated by the output of this sector, Economic Survey (2001 - 02). SME sector in Pakistan is comprised of cotton weaving, wood and furniture, metal products, art silk, grain milling, jewelry, carpets, sports goods, pottery, dairy and poultry, fisheries, food and catering, and slaughtering.

The situation of industrial sector in Pakistan is bleak. The large-scale industries are, mostly, urban based where as the most of the SMEs are located in small towns and rural areas. These SME units located in rural localities are of great importance for the provision of employment to poor rural workers, Qureshi and Ghani (1989). SME sector in has got very much importance in Pakistan. A well-developed modern SME sector, in a more open economy, is a complement. Many developing counties have been reaping the benefits of the export orientation of this sector, Berry (1998). The present examines the impact of small scale industries' performance on poverty levels in Pakistan.

\section{Review of literature}

The pioneer studys in development economics by Lewis, Nurkse and Rosenstein-Rodan focused on national development. The authors were less interested in the impacts of economic development on the poor. These development theorists were proponents of the 'trickle-down' impacts of economic growth to the poor Lipton and Ravallion (1995). Some of the development economists have been of the opinion that robust growth and sustained development can be obtained through development of capital intensive large scale enterprises, Loveman and Sengenberger (1991). 
Adelman and Robinson (1989) are of the opinion that the development more often takes place in urban areas than that in rural areas so the poor are not benefited by the process of development. The growth of unskilled labor-intensive sectors may be helpful for the poverty reduction and equal distribution of income, World Bank (1990) and Alderman and Robison (1989). The growth of labor-intensive industries may ensure the greater involvement of the poor and better utilization of cheaper inputs that may be the labor. The utilization of low-wage workers in the production process, if low wages are high enough for reducing poverty and low enough for competing in the market with the rivals, make the labor-intensive industries competitive in international market and be helpful in poverty reduction simultaneously. Sen (1960) and Myrdal (1968) emphasized on the roles of labor-intensive industrialization on poverty reduction. The utilization of labor and human capital accumulation of the poor for the poverty reduction is important, World Bank (1990).

In recent years the importance of SMEs for the contributions in economic growth and development of the economies has been recognized. SMEs employ much more labor force than the huge multinational corporations, Mullineux (1997). Due to dynamic and evolutionary nature of small scale firms "serve as agents of change", Audretsch (2000). SME sector has been a source of concern for the policy makers for the accelerated growth in developing nations. SMEs are a major source of potential employment in low income economies. That is why these enterprises are considered to be the "engine of growth" for the attainment of growth objectives in developing nations, Advani (1997). The initiatives for the promotion of SMEs by the governments of the recent times, especially in developing countries, are underway, Feeny and Riding (1997). Wider economic and socioeconomic objectives such as poverty alleviation can be achieved by developing the SMEs, Cook and Nixon (2000). There is a low cost associated with the job creation in SMEs and these enterprises are more labor intensive than the larger firms, [Leidholm and Mead (1987); Schmitz (1995)].

Since the SMEs are more labor intensive and these type of firm are more likely to be based in rural areas and smaller urban areas so development of the SMEs may be helpful for the economic satiability, growth and employment. The dispersion of these enterprises in these areas and their labor intensity may be very important in equal distribution of income than the large firms. The development of SMEs helps the economies to grow in the long run these enterprises improve domestic market efficiency and uses the scarce resources productively, Kayanula and Quartey (2000).

Mukras (2003) suggests set of policy recommendations for poverty alleviation through strengthened SMEs. Strengthened SMEs generate employment and economic growth in the economy. The proponents of pro-MSMEs are of the argument that entrepreneurial and innovative ventures in MSMEs help to improve growth of the economy and reduce the poverty levels in developing economies, Beck et al. (2004). Small scale enterprises increase competition and entrepreneurship in the economy and result in economy wide benefits in efficiency, innovation and growth in productivity. Gebremarian et al. (2004) analyzing the relationship between development of small scale business, growth and incidence of poverty in West Virginia found a strong negative relationship between small scale business and the incidence of poverty. Beck et al. (2005) exploring the relationship between SMEs, growth and poverty find a strong and strong relationship between the importance of SMEs and growth in GDP per capita. The study does not confirm the poverty alleviating impact of SMEs in a sample of 45 countries. Since the Small scale medium enterprises are more labor intensive so growth in these enterprises increases employment more than the large scale industries' growth, Snodgrass and Biggs (1996). SMEs generate income and increase employment in the economy, Lukas (2005). Aina and Amnes (2007) suggest more effective and fully funded policy program for the development of SMEs in Nigeria, for generating employment opportunities for economic growth, to empower the poor and deprived.

The adoption of growth strategies that helped to promote labor-intensive industries and SMEs promoted high levels of growth with low levels on income inequality in Republic of Korea and Taipei, China during 1950s - 1990s, Li and Lou (2008). The absorption of rural surplus labor and reduction in urban unemployment due to establishments of these small and medium enterprises helped these economies to growth with low inequality. The People's Republic of China (PRC), though, has shown robust and high levels of growth but income inequality increased during last 3 decades. The authors suggest the unification of labor market and encouragement of SMEs, more laborintensive development policy, for better growth and more equal distribution of income in PRC.

Some of the studies focus on how much SMEs sector contributes to the GDP and employment that it generates in the economy. SME sector has been playing a very important role in development, employment generation and poverty alleviation in African economies. About $85 \%$ of the manufacturing employment in Ghana is provided by the SME sector. This sector consists of $92 \%$ of business and contributes $70 \%$ of the GDP in Ghana. Where as in South Africa, this sector contributes to $52-57 \%$ of the GDP and provides $61 \%$ of employment. SMEs constitute $91 \%$ of the formal business in South Africa, Abor and Quartey (2010). The authors also suggest appropriate strategy for the improvement in Ghana and South Africa.

Agyapong (2010) discusses the role of micro, small and medium enterprises (MSMEs) in poverty alleviation in Ghana. The author is of the view that town and rural based MSMEs help to create jobs and increase income of the people. This increased income helps the people to obtain better schooling, health facilities and empowers them to get rid of vicious circle of poverty. Furthermore, growth in small and medium enterprises (SMEs) also contributes to human capital through on job training. The author is also of the view that MSMEs also contribute in the increase of tax revenue of the government.

\section{Data and methodology}

This study focuses on the impact of small scale enterprises (S) on poverty measured by poverty head count ratio $(\mathrm{H})$ in Pakistan for the period $1972-2008$. The impact of income inequality measured by Gini coefficient (I), education expenditure as percentage of GDP (E) and inflation measured by consumer price index $(P)$ on poverty is also analyzed. Annual time series data is used for all of the variables. We have used small scale industries output as percentage of GDP as proxy variable of small scale enterprises. The data of small scale industries' output as percentage of total manufacturing output (S) and education expenditure as Percentage of GDP (E) is taken from the Statistical Handbook (2010) of State Bank of Pakistan. We have taken annual poverty Head Count Ratio (HCR) and income inequality measured by Gini coefficient 
(GINI) from Annual Economic Survey (Various Issues) of the Ministry of Finance, Government of Pakistan. The consumer price index $(\mathrm{CPI})$ has been taken from the World Development Indicators (WDI) (2008) of the World Bank.

In our analysis, poverty is function of income inequality (I), small scale enterprises output as percentage of total manufacturing output (S), education expenditure as percentage of GDP $(E)$ and inflation $(P)$. We have estimated the following model:

$\mathrm{H}=\mathrm{f}(\mathrm{l}, \mathrm{S}, \mathrm{E}, \mathrm{P})$

$\mathrm{LH}_{\mathrm{t}}=\alpha+\beta 1 \mathrm{LI}_{\mathrm{t}}+\beta 2 \mathrm{LS}_{\mathrm{t}}+\beta 3 \mathrm{LE}_{\mathrm{t}}+\beta 4 \mathrm{LP}_{\mathrm{t}}+\varepsilon \mathrm{t}$

where

$\mathrm{LH}=$ Log of Poverty Head Count Ratio

$\mathrm{LI}=\mathrm{Log}$ of Gini Coefficient

LS = Log of Small scale industries' output as a percentage of total manufacturing output

$L E=\log$ of education expenditure as percentage of GDP

LP $=$ Log of Consumer Price Index

$\varepsilon_{\mathrm{t}}=$ Error term

It has become norm to examine the order of integration of the time series prior to the modeling to modeling the time series. This diagnostic process requires the time series to be stationary. A univariate analysis of each of the time series included in the model is carried out to test the presence of a unit root. Since time series data is used in the analysis so we have used Augmented Dickey-Fuller (ADF) unit root test the order of integration. This study applies ADF unit root test without drift and without trend in the data.

When the time series are integrated of the same order, that is, they are stationary at same level then the time series are cointegrated. It implies that there exists an equilibrium or long run relationship between them, Engle and Granger (1987). A cointegration technique tests the long run or equilibrium relationship among the non-stationary time series integrated of the same order. This analysis applies the Johansen $(1990,1995)$ cointegration techniques. Johansen and Juselius (1991) introduced, in the multivariate cointegration test, the two likelihood ratio tests (Maximumeigen value and Trace tests) to find out the number of cointegrating vectors. If the time series are cointegrated, then, in the short run, there may be disequilibrium. The error term is tied to short run behavior of the dependant variable to its long run value. If two variables are cointegrated then the relationship between these variables can be expressed as the Error Correction Mechanism (ECM). ECM, first, was introduced by Sargan (1984) and then it was popularized by Engle and Granger (1987). The present study applies Johansen $(1990,1995)$ cointegration test to find out cointegrating vectors and ECM model is applied to examine the short run behavior of the variables.

\section{Results and discussions}

\section{Unit Root Test}

It has been a common practice, in applied econometric analyses, to test the order of integration of time series. The study applies ADF unit root test, at level and at the first difference of the time series with assumption of no drift and tend, to have the information about the order of a time series. ADF test results reported in the Table 1 are evident that we are unable to reject the null hypothesis for the presence of a unit root at level of each of the time series. All of the time series are stationary at their first difference.
Since each of the time series is stationary at its first difference so the variables are cointegrated. There exists an equilibrium or long run relationship between the time series if all the variables are integrated of the same order, Engle \& Granger (1987). The study applies Johansen cointegration technique. Johansen and Juselius (1991) introduced, in the multivariate cointegration test, the two likelihood ratio tests (Maximum-eigen value and Trace tests) to find out the number of cointegrating vectors. An Akaike AIC criterion is used to select the appropriate lag length. We used maximum eigen value test to find out the number of cointegrating vectors. Results of the Johansen $(1990,1995)$ cointegration test (see Table 2) show that likelihood ratio test concludes 4 cointegrating vectors at $95 \%$ level of confidence.

Table 1: ADF Unit Root Results

\begin{tabular}{|l|l|l|l|}
\hline \multirow{3}{*}{ Variable } & \multicolumn{3}{|l|}{ ADF Statistic (Without Drift \& Trend) } \\
\cline { 2 - 4 } & Level & $1^{\text {st }}$ Difference & $p$-value* \\
\hline LH & -1.4301 & $-3.4459^{* *}$ & 0.0000 \\
\hline LI & 0.1186 & $-5.3479^{* *}$ & 0.0000 \\
\hline LS & -0.6884 & $-6.3567^{* *}$ & 0.0000 \\
\hline LE & 0.1654 & $-6.4850^{\text {** }}$ & 0.0000 \\
\hline LP & 0.1301 & $-6.5488^{* *}$ & 0.0001 \\
\hline
\end{tabular}

*MacKinnon (1996) one-sided p-values.

${ }^{* *}$ Rejected the $\mathrm{H}_{0}$ of unit root at $1 \%$ significance level.

Source: Author

\section{The impact of SMEs on poverty in Pakistan}

The Gini index elasticity of poverty is -1.2326 (see Table 2), it implies that income inequality increases poverty levels in Pakistan. The elasticity shows that one percent increase in Gini coefficient increases the poverty measured by HCR by 123.26 percent. The elasticity is significant at 10 percent level of significance. This poverty increasing impact of income inequality in Pakistan may be due to the fact that increase in income inequality may affect growth. Aggregate saving in a country may increase with the increase in the income inequality if the rich people in the economy save high proportion of their income than the low income groups. This higher saving level would be source of high levels of investment and increased growth. Income distribution impacts growth through economic, political or social channels, Voitchovsky (2005).

Table 2: Results of Johansen Cointegration Test (Lag Length = 3)

\begin{tabular}{|l|l|l|l|l|}
\hline \multirow{2}{*}{$\begin{array}{l}\text { Null } \\
\text { Hypothesis }\end{array}$} & Likelihood & \multicolumn{2}{|l|}{ Critical Value } & Eigen \\
\cline { 3 - 4 } & Ratio & 5 Percent & 1 Percent & \\
\hline None $^{* *}$ & 166.2014 & 76.0700 & 84.4500 & 0.8611 \\
\hline At most $1^{* *}$ & 101.0545 & 53.1200 & 60.1600 & 0.7681 \\
\hline At most 2* & 52.8225 & 34.9100 & 41.0700 & 0.6202 \\
\hline At most 3 & 20.8758 & 19.9600 & 24.6000 & 0.3451 \\
\hline At most 4 & 6.9085 & 9.2400 & 12.9700 & 0.1889 \\
\hline
\end{tabular}

$\left.{ }^{*}{ }^{* \star}\right)$ denotes rejection of the hypothesis at $5(1) \%$ significant level. L.R. Test indicates 4 cointegrating equations at $5 \%$ level of significance.

Source: Author

Low levels of poverty can be achieved either through achieving the goal of higher levels of growth or improved distribution of income, or both. Datt and Ravallion (1992) Kakwani, (1993) and Bourguignon (2001, 2003, 2004) establishing a relationship between poverty alleviation, economic growth, and changes in income distribution concluded that combination of economic growth and income distribution determines the direction and incidence of 
poverty. The total effect of economic growth can be poverty augmenting if economic growth has negative impact on distribution of income.

Small scale industries' output as percentage total manufacturing output showed negative and significant impact on poverty in Pakistan. This may be due to the fact that small scale enterprises use more labor than that is employed by large scale firms. SMEs play key role in the acceleration of pro-poor growth in the economy. Since the SME sector employs about 80 percent of the non-farm labor force in Pakistan so the role of the SME sector in ensuring the fruits of the economic growth to be equitably distributed. Economic survey of Pakistan (2003 - 04) reports that SMEs contribute in employment generation and poverty reduction in Pakistan as 90 percent of all of the industrial enterprises employ less than 99 workers. SMEs contribute about 30 percent to the GDP of the Pakistan economy and this sector employs 80 percent of the non-agriculture labor force.

Education expenditure as percentage of GDP showed poverty increasing impact and this impact is statistically significant. Education expenditure elasticity of poverty is -2.4592 it means one percent increase in education expenditure as percentage of GDP causes an increase of 245.92 percent in poverty head count index in the long run in Pakistan. Education expenditure in Pakistan also shows poverty increasing impact in the short run. Results of the ECM model, for the analysis of short run impacts on poverty, are reported in the Table 3 . The traditional proponents of human capital theories are of the view that cognitive abilities of workers are increased and therefore labor productivity is increased with the increase in schooling. According to traditional view of human capital theorists higher productivity levels of the workers are positively related to the education levels received. Across the globe, it has been recognized that higher levels of education increases the probability of finding employment and the workers with higher levels of education earn higher incomes.

\begin{tabular}{|l|l|l|l|}
\hline \multicolumn{4}{|l|}{ Table 3: Johansen Cointegration Coefficients } \\
\hline Variable & Coefficient & Standard Error & t-ratio \\
\hline constant & $-7.8746^{*}$ & 1.5133 & -5.2036 \\
\hline Income Inequality & $-1.2326^{\star *}$ & 0.8504 & -1.4495 \\
\hline Small Scale Industries & $1.8714^{*}$ & 0.3836 & 4.8781 \\
\hline Education Expenditure & $-2.4592^{*}$ & 0.5204 & -4.7257 \\
\hline Inflation & $-0.4102^{*}$ & 0.0805 & -5.0987 \\
\hline $\begin{array}{l}\text { * Significant at 1 percent level of significance } \\
\text { ** significant at 10 \% level of significance }\end{array}$ \\
\hline Source: Author
\end{tabular}

The inflation elasticity of poverty with positive sign shows that inflation exerts a negative impact on poverty levels in Pakistan. But the coefficient of inflation is not significant. Our result does not support the relationship between inflation and poverty explained by the economic theory. In economic theory increase in inflation, in short run, is associated with increase in employment levels in the economy. Increase in inflation reduces the purchasing power of the low income segments of the population due to the vulnerability of these people to inflationary pressures in the economy, Kalim and Shahbaz (2009). Inflation effects poverty through its impact on real wages in the economy. Real wages, Latin America, increase slowly than the increase in inflation during the times of high inflation, Cardoso (1992). This increase in employment benefits the strived in the economy. Agenor (1998) and Chaudhry et al. (2010) strengthen the conclusion of positive relationship between inflation and poverty.

\section{Short run behaviour of the variables}

As the variables are cointegrated, that is, there exist a long run and/or equilibrium relationship between them. If the variables are cointegrated then, according to Granger representation theorem, then the relationship between the variables can be expressed as ECM. The coefficient of the $\operatorname{ECM}(-1)$ is -0.2412 (see Table 4) that is negative it implies that $\Delta \mathrm{LH}_{\mathrm{t}}$ would be negative to restore the equilibrium. It means if the $\mathrm{LH}_{\mathrm{t}}$ is above it equilibrium value, it would start falling in the next period the correct the equilibrium error. ECM term is statistically significant at 1 percent significance level showing that 24.12 percent of discrepancy between the long run and short run $H$ is corrected within a year.

The results of the ECM model show that two and three year differenced values of poverty head count ratio have positive and statistically significant affect in the current year poverty levels in the country. This shows that poverty has is affected by the past years poverty levels in Pakistan. Inflation also affects the poverty levels in Pakistan in the short run period but at the level of significance of 10 percent.

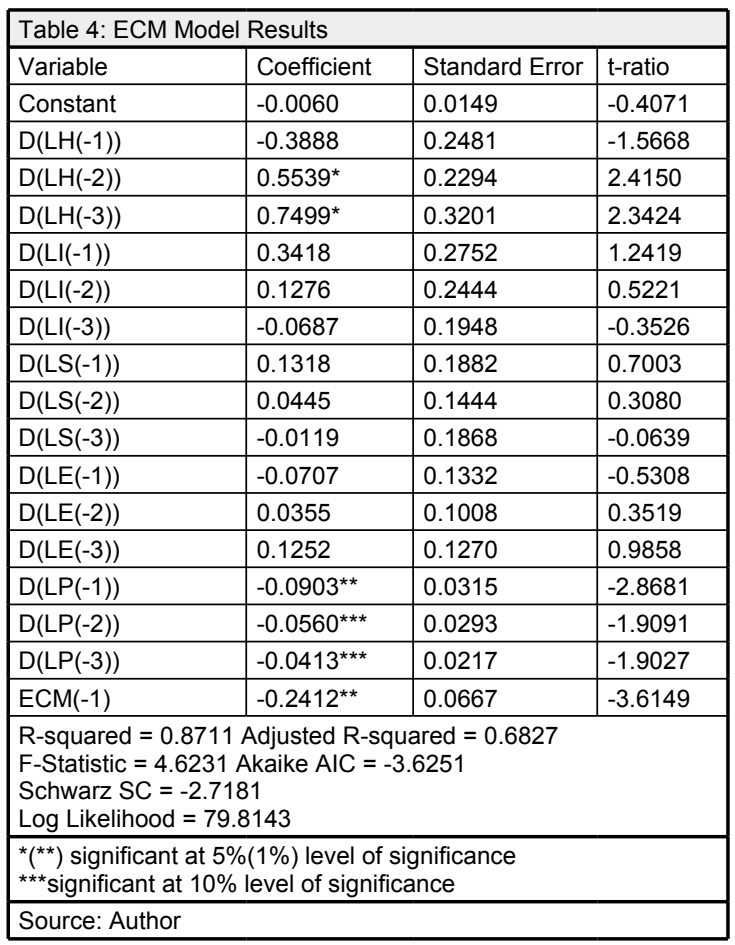

The results of the error correction model (see Table 4) are evident that one and tow year back values of small scale industries output increase poverty levels but three year differenced value of small scale industries output decreases poverty levels in Pakistan but these results are insignificant.

The education and poverty are connected through direct and indirect (externalities) mechanisms. Firstly, educated labor earns higher income. More education improves the prospects of economic growth of the economy and improved growth of the economy increases the employment opportunities and incomes in the economy. Increased education also results in social benefits. These social benefits not only help improving the economic development 
but also help to improve the situation of the poor for example lower fertility rates, better health services attainment and female participation in labor force, Berg (2008). Better education services in the economy help to improve the human capital and better human capital increases the productivity of labor. Higher productivity of labor results in higher income earned and reduction in poverty. The provision of better education services in an economy provides economic security and helps the poor to grow and reduces poverty. Better education services help reduce poverty and lower poverty levels improves health of the poor. Policy makers should focus on the better health and services so that the poor may get out of the vicious cycle of poverty. Thaver and Bhutta (2006) discuss poverty and ill health links with reference to Pakistan economy.

The education system of Pakistan is not only region biased but also gender biased. As the literacy rates in rural Pakistan is 49 percent against the 74 percent literacy rate in urban Pakistan. Whereas the female literacy rate is only 46 percent against the male literacy rate of 69 percent, Economic Survey of Pakistan (2010 - 11). The story does not end here. The education system of Pakistan is such that conditions of the government schools in the remote areas is the worst and common man cannot even think of high standard education as the high standard educational institutions are unaffordable for the them.

Inflation has no significant on poverty levels, in short run, on poverty levels in Pakistan. But in long run it causes an increase in the poverty levels in Pakistan. Due high levels of population, purchasing power of the low income groups is reduces. More people slip from the middle income brackets to the low income groups and become more vulnerable. Economy requires a higher growth rates with increased employment level but at low levels of inflation.

\section{Conclusion}

This study focuses on the impact of small scale industries on poverty in Pakistan. We have used annual time series data for the period of $1972-2008$. The analysis incorporates the cointegration techniques and ECM models for the long run and short run effects of Inflation, health expenditure, population growth rate, income inequality. Prior to the application of cointegration analysis, the study uses ADF unit root test on each time series to be stationary at its first difference at level. The study reviews the earlier empirical studies on the relationship between small scale enterprises and poverty. This paper represents the descriptive analysis of the explanatory variables and trends in poverty and small scale industries' output.

There is dire need to focus on the income inequality situation in Pakistan. Income inequality is very important for the reduction in poverty levels in the economy. The negative relationship between income inequality and poverty implies that a better redistribution policy would be beneficial for the process of poverty alleviation.

The poverty reducing impact of increase in small scale industries' output has been concluded. The result is significant. This implies that small scale enterprises can play very important role in the economic growth, employment generation and poverty alleviation in Pakistan. The results of the study imply that a strong SME base is required for the development of the economy and poverty alleviation in Pakistan. The economic policy makers must focus on the establishment of formal financial markets to overcome the financial constraints faced by the SME sector in Pakistan. Simplification of lending procedures, enforcement of credit rights, and reduction in credit costs would be helpful for the establishment of robust SME sector in Pakistan. More over provision more educated and technically skilled labor force would accelerate the growth of the SMEs and would be helpful in the process of poverty reduction. Pakistan economy has been facing energy crises for many years. This energy crisis has dwindled the industrial sector in Pakistan. So a strong energy policy would be fruitful to overcome the shortage of energy in the economy.

\section{REFERENCES}

1. Abor, J. and Quartey, P. (2010). Issues in SME Development in Ghana and South Africa. International Research Journal of Finance and Economics, 39: 218 - 228.

2. Adelman, J. and S. Robinson (1989). Income Distribution and Development, in Chenery, HI Srinivasan, T. N. (eds), Handbook of Development Economics, Vol. II, Amsterdam: Elsevier Science Publishers B. V. Chapter 9, pp. 949 - 1003.

3. Advani, A. (1997). Industrial Clusters: A Support System for Small and Medium-Sized Enterprises, Private Sector Development. World Bank Occasional Paper No. 32, World Bank, Washington, DC.

4. Afzal, Mohammad (2009). Population Growth and Economic Development in Pakistan. The Open Demography Journal, 2: 01 07.

5. Agenor, Pierre-Richard (1998). Stabilization Policies, Poverty and the Labor Market, Mimeo, IMF and World Bank.

6. Agyapong, Daniel (2010). Micro, Small and Medium Enterprises' Activities, Income Level and Poverty Reduction in Ghana-A Synthesis of Related Literature. International Journal of Business and Management, 5(12): $196-205$.

7. Aina, Olayinka Chris Mnitp, RTP, Amnes (2007). The Role of SMEs in Poverty Alleviation in Nigeria. Journal of Land Use and Development Studies, 3(1):124 - 131

8. Audretsch, David B. (2000). The Economic Role of Small and Medium-Sized Enterprises: The United States.

9. Beck, T., Demiruc-Kunt, A., and Livine R. (2005). SMEs, Growth and Poverty: A Cross-Country Evidence. Journal of Economic Growth, 10: 199 - 229.

10. Beck, T., Demiruc-Kunt, A., and Maksimovic, V. (2004). SMEs, Growth and Poverty-Do Pro-SME Policies Work? World Bank Policy Research Working Paper No. 268.

11. Berg, S. Van Der. (2008). Poverty and Education. Paris: International Institute for Educational Planning and Internal Academy of Education.

12. Berry, Albert (1998). The Potential Role of the SME Sector in Pakistan in a World of Increasing International Trade. The Pakistan Development Review, 37(4): 25 - 49.

13. Bolton, J. E. (1971). Report of the Committee of Inquiry on Small Firms. HMSO, London.

14. Bourgnuignon, F. (2004). The Poverty-Growth-Inequality Triangle. Paper presented at the Indian Council for Research on International Economic Relations, New Delhi, on February 4.

15. Bourguignon, F. (2003). The Growth Elasticity of Poverty Reduction: Explaining Heterogeneity across Countries and Time Periods. In Eicher, T. S., Turnovsky, S. J. (eds), Inequality and Growth: Theory and Policy Implications, Cambridge: MIT Press.

16. Bourguignon, G. (2001). The Pace of Economic Growth and Poverty Reduction. Paper presented at LACEA 2001 Conference, Montvideo, Uruguay (http://www. Nip-lac.org/programs_lacea/ Bourguignon.pdf).

17. Cardoso, Eliana (1992). Inflation and Poverty. NBER Working Paper No. 4006.

18. Chaudhry, Imran Sharif (2009). Poverty Alleviation in Southern Punjab (Pakistan): An Empirical Evidence from the Project Area of Asian Development Bank. International Research Journal of Finance and Economics, 23:23 - 32.

19. Chaudhry, Imran Sharif; Malik, Shahnawaz; Hassan Abo UI. and Faridi, Muhammad Zahir (2010). Does Education Alleviates Poverty? 
Empirical Evidence from Pakistan. International Research Journal of Finance and Economics, 52: 134 - 141.

20. Cook, P. and F. Nixon (2000). Finance and Small and MediumSized Enterprise Development. IDPM, University of Manchester, Finance and Development Research Programme Working Paper Series, Paper No. 14.

21. Datt, G. and Ravallion, M. (1992). Growth and Redistribution Components of Change in Poverty Measure: A Decomposition with Applications to Brazil and India in the 1980's. Journal of Development Economics, 38(2): 275 - 295.

22. Durbin, J. (1970). Testing for Serial Correlation in Least-Squares Regression When Some of the Regressors Are Lagged Dependant Variable. Econometrica, 38: 410 - 721 .

23. Economic Survey of Pakistan (Various Issues). Ministry of Finance, Government of Pakistan: Islamabad.

24. Engle, R. F. k, and Granger, C. W. (1987). Cointegration and Error Correction: Representation, Estimation and Testing, Econometrica, 55, $251-276$.

25. Feeny, L. S. and A. L. Riding (1997). Business Owners' Fundamental Tradeoff: Finance and the Vicious Circle of Growth and Control. Canadian Business Owner, November.

26. Gebremarian, G. H., Gebremedhin, T. G., and Jackson, R. W. (2004). The Role of Small Business in Economic Growth and Poverty Alleviation in West Verginia: An Empirical Analysis. The paper at the American Agricultural Economics Association Annual Meeting, Denver, Colorado, August $1-4$.

27. Granger, C. W. F. (1988). Some Recent Developments in a Concept of Causality. Journal of Ecnometrica, 39: 199-211.

28. Johansen, S. (1991). Estimation and Hypothesis Testing of Cointegration Vectors in Gaussian Vector Autoregressive Models. Econometrica, 59(6), 1551 - 1580.

29. Johansen, S. (1995). Likelihood-based Inference in Cointegrated Vector Autoregressive Models. Oxford University Press.

30. Johansen, S., \& Juselius K. (1990). Maximum Likelihood Estimation and Inferences on Cointegration with Application to the Demand for Money. Oxford Bulletin of Economics and Statistics, 52(2), $169-210$.

31. Jordan, J., J. Lowe, and P. Taylor (1998). Strategy and Financial Policy in U.K. Small Firms. Journal of Business Finance and Accounting, 25(1/2):1 - 27.

32. Kakwani, N. (1993). Poverty and Economic Growth with Application to Cote D'Ivoire. Review of Income and Wealth, 39(2): $121-139$.

33. Kalim, Rukhsana and Mohammad Shahbaz (2009). Remittances and Poverty Nexus: Evidence from Pakistan. International Research Journal of Finance and Economics,29: 46 - 59.

34. Kayanula, D., and P. Quartey (2000). The Policy Environment for Promoting Small and Medium-Sized Enterprises in Ghana and Malawi. Finance and Development Research Programme, Working Paper Series, Paper No. 15, IDPM, University of Manchester.

35. Li, Shi and Luo, Ghuliang (2008). Growth Pattern, Employment, and Income Inequality: What the Experience of Republic of Korea and Taipie, China Reveals to the People's Republic of China. Asian Development Review, 25(1 and 2): $100-118$.

36. Liedholm, C. and D. Mead (1987). Small Scale Industreis in Developing Countries: Empirical Evidence and Policy Implications. International Development Paper No. 9., Department of Agriculture Economics, Michigan State University, East Lansing, MI, USA.

37. Lipton, M. and Ravallion, M. (1995). Poverty and Policy. In Behrman, J., Srinivasan, T. N. (eds), Handbook of Development Economics, Vol. IIIB, Amsterdam: Elservier Science B. V.: pp. 2551 $-2657$.

38. Loveman, G., and Sengenberger, W. (1991). The Re-emergence of Small Scale Production: An International Comparison. Small Business Economics, Vol. 3.

39. Lukas, E. (2005). The Economic Role of SMEs in World Economy, Especially in Europe. http//www.uni-miskolc.hu/uni/res/ kozlemenyek/2005/pdf/lukacs.doc
40. Malik, Sohail J. (2005). Agriculture Growth and Rural Poverty: A Review of the Evidence. Pakistan Resident Mission Working Paper Series, Working Paper No. 2 : Asian Development Bank.

41. Mukras, M. S. (2003). Poverty Reduction Through Strengthening Small and Medium Enterprises. Botswana Journal of African Studies, 17(2): $58-69$.

42. Mullineus, A. W. (1997). The Funding of Non-Financial Corporations (NFCs) in the EU (1971 - 1993): Evidence of Convergene. Mimeo, Department of Economics, University of Birmingham.

43. Myrdal, Gunner (1968). Asian Drama: An Inquiry into the Poverty of Nations. New York Pantheon.

44. Qureshi, S. K. and Ghani, E. (1989). Emplyment Generation in Rural Pakistan with a Special Focus on Rural Industrialization: A Preliminary Analysis. The Pakistan Development Review, 28(4): 587 $-402$.

45. SBP Annual Report (Various Issues). State Bank of Pakistan, Karachi.

46. SBP Statistical Handbook (2010). State Bank of Pakistan, Karachi.

47. Schmitz, H. (1995). Collective Efficiency: Growth Path for Small Scale Industry. Journal of Development Studies,31(4): $529-566$.

48. Sen, A. K. (1960). Choice of Techniques: An Aspect of the Theory of Planned Economic Development. Oxford: Basil Blackwell.

49. Todar, M. P and Smith, S. C. (2009). Population Growth and Economic Development in Economic Development, Ed. 10, Published by Prentice Hall, PP295 - 309.

50. UNIDO (2007). Creative Industries and Micro \& Small Scale Enterprise Development: A Contribution to Poverty Alleviation. Project XP/RAS/05/002, United Nations Industrial Development Organizaiton: Austria.

51. Voitchovsky, Sarah (2005). The Effect of Inequality on Growth: A Review of the Recent Empirical Literature. DFID Commissioned Study.

52. World Bank (1990). World Development Report 1990: Poverty, New York: Oxford University Press.

53. World Bank (2008). Wolrd Development Indicators, Washington D.C., December. 